\title{
Development and Validation of RP-HPLC method for determination of Modafinil in bulk and dosage form
}

\author{
${ }^{*}$ Chusena Narasimha Raju Bhimanadhuni ${ }^{1}$, Devala Rao Garikapati², Swetha Karamsetty ${ }^{3}$ \\ ${ }^{1}$ Research Scholar, Department of Pharmaceutical analysis, Prist University, Thanjavur, Tamilnadu, India \\ ${ }^{2}$ Department of Pharmaceutical analysis, K.V.S.R Siddhartha College of pharmaceutical sciences, Vijayawada, \\ Krishna(Dt), Andhra Pradesh, India \\ ${ }^{3}$ Department of Pharmaceutical analysis, Browns college of Pharmacy, Khammam, Andhra Pradesh, India
}

\begin{abstract}
A reverse phase high performance liquid chromatographic method was developed for the determination of Modafinil in bulk and dosage form. The separation was effective on a Hypersil ODS $C_{18}$ column (250 mm x $4.6 \mathrm{~mm}$; $\left.5 \mu\right)$ using a mobile phase mixture of Buffer:Acetonitrile in a ratio of $55: 45(\mathrm{v} / \mathrm{v})$ at a flow rate of $1.0 \mathrm{ml} / \mathrm{min}$. The detection was made at $220 \mathrm{~nm}$. The retention time of modafinil was found to be $4.80 \pm 0.06 \mathrm{~min}$. Calibration curve was linear over the concentration range of $20-120 \mu \mathrm{g} / \mathrm{ml}$ of modafinil. The proposed method was validated as per the ICH guidelines. The method was accurate, precise, specific and rapid and thus found to be suitable for the quantitative analysis of modafinil in the bulk and dosage form.
\end{abstract}

Key Words: Method development, validation, Modafinil, Tablets, Hypersil C 18 Column, RP-HPLC.

\section{INTRODUCTION}

Modafinil (The Merk Index, 2001) belongs to the class narcoleptics. It is chemically 2- [(diphenyl methyl)-Sulfinyl]acetamide. A literature survey reveals a few methods for quantification of modafinil and its acid metabolite in human plasma (Moachon and Matinier, 1994); determination of modafinil and its two metabolites in human plasma using solid-phase extraction (Burnat et al., 1998); quantitative analysis of modafinil in plasma and urine (Schwertner et al., 2005); method to separate and quantitate the enantiomers (d- and 1-) of modafinil in human serum (Donovan et al., 2003); determination of enantiomers of modafinil and its two major metabolites using a bi-dimensional HPLC system by coupling chiral column (Cass and Galatti, 2007); method for separation and determination of related substance, viz, sulphide, sulphoxide, sulphones, acid and ester derivatives of modafinil (Nageswara et al., 2007);

\footnotetext{
*Corresponding Author:

Ch Narasimha Raju Bh, Department of Pharmaceutical analysis

Annabattuni Satya Narayana Pharmacy College

Burripalem Road, Tenali-522201

Guntur (Dt), Andhra Pradesh

E-mail: bhchnraju@yahoo.com
}

determination of optical isomers of modafinil and modafinil acid (YU and Chovan, 1999) etc. The present investigation by the authors describes a rapid, accurate, precise and specific RP-HPLC method for the determination of modafinil from bulk sample and pharmaceutical dosage form. It is not official in any of the pharmacopoeia. The detector responses were linear in the concentration range of $20-120 \mu \mathrm{g} / \mathrm{ml}$ of drug. The method was validated as per ICH guidelines.

\section{EXPERIMENTAL}

\section{Chromatographic Conditions}

Shimadzu with high pressure liquid chromatographic instrument provided with a Hypersil ODS C18 column (250 mm x $4.6 \mathrm{~mm} ; 5 \mu$ ) and LC 20 AD Pump and Prominence SPD 20A UV-deuterium detector was employed in the study. A $20 \mu \mathrm{L}$ Hamilton injection syringe was used for sample injection. Data acquisition was performed by using Spinchrome software, Shimadzu Class VP version 6.12 SPS data system. HPLC grade water, methanol, acetonitrile were purchased from E. Merck Co., Mumbai, India, and Potassium dihydrogen ortho phosphate, dipo- 


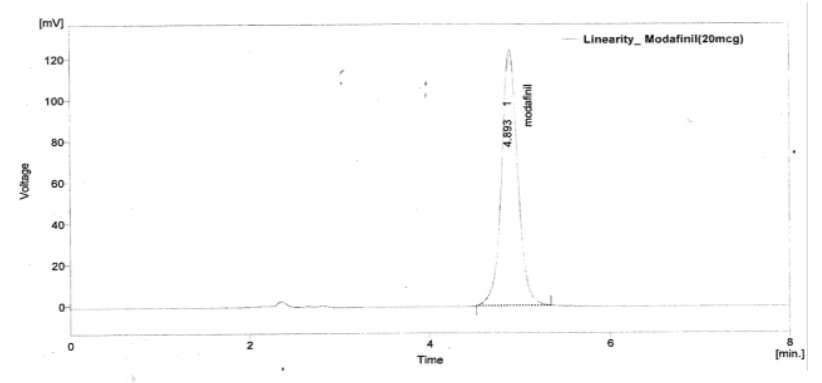

Result Table (Uncal - Linearity_ Modafinil(20mcg))

\begin{tabular}{|c|c|c|c|c|}
\hline & $\begin{array}{c}\text { Reten. Time } \\
{[\mathrm{min}]}\end{array}$ & $\begin{array}{c}\text { Area } \\
{[\mathrm{mV} . \mathrm{s}]}\end{array}$ & $\begin{array}{c}\text { Height } \\
{[\mathrm{mV}]}\end{array}$ & $\begin{array}{c}\text { Area } \\
{[\%]}\end{array}$ \\
\hline 1 & 4.893 & 1548.888 & 124.350 & 100.000 \\
\hdashline & Total & 1548.888 & 124.350 & 100.000 \\
\hline
\end{tabular}

Column Performance Table (From 50\% - Linearity Modafinil(20mcg)

\begin{tabular}{|c|c|c|c|c|c|}
\hline & $\begin{array}{c}\text { Reten. } \\
\text { Time }\end{array}$ & $\begin{array}{c}\text { W05 } \\
{[\mathrm{min}]}\end{array}$ & $\begin{array}{c}\text { Asymmetry } \\
{[-]}\end{array}$ & $\begin{array}{c}\text { Efficiency } \\
{[\text { th. pl] }}\end{array}$ & $\begin{array}{c}\text { Resolution } \\
{[-]}\end{array}$ \\
\hline 1 & 4.893 & 0.187 & 1.036 & 3807 & - \\
\hline
\end{tabular}

Figure 1: Chromatogram of Modafinil $20 \mu \mathrm{g} / \mathrm{ml}$.

tassium hydrogen ortho phosphate AR grade were purchased from S D Fine Chem Limited, Mumbai, India.

\section{Drug samples}

The reference sample and branded formulation of modafinil was supplied by M/s Orchid Pharmaceuticals, Chennai, India.

\section{Mobile phase}

Accurately $1.36 \mathrm{~g}$ of potassium dihydrogen phosphate was weighed out and dissolved in $550 \mathrm{ml}$ of water. $0.3 \mathrm{~g}$ of dihydrogen potassium phosphate was weighed out and dissolved in $450 \mathrm{ml}$ of water. Both solutions were mixed to prepare buffer solution. The solution was filtered through $0.45 \mu$ membrane filter and was degassed. A freshly prepared binary mixtures of buffer:acetonitrile in a ratio of (55:45) $\mathrm{V} / \mathrm{V}$ was used as the mobile phase. Methanol was used as diluent for preparing the working solution of the drug. The mobile phase was filtered through $0.05 \mu$ membrane filter and sonicated by using Power Sonicator, model no:405, Hwashin Technology, Korea before use. The flow rate of the mobile phase was maintained at $1 \mathrm{ml} / \mathrm{min}$. The column temperature was maintained at $25^{\circ} \mathrm{C}$ and the detection of the drug was carried out at $220 \mathrm{~nm}$.
Preparation of stock and working standard solution of modafinil

About 100mg of modafinil was weighed accurately and transfer in to $100 \mathrm{ml}$ volumetric flask the solution was sonicated and filter through Whatman filter paper, resulting solution was diluted with the mobile phase to get a working standard solution of $100 \mu \mathrm{g} / \mathrm{ml}$ of modafinil.

\section{Linearity and construction of calibration curve}

The quantitative determination of the drug was accomplished by a standard method. The column was equilibrated with the mobile phase for at least 30 min prior to the injection of the drug solution. Linearity of the peak area response was determined by taking measurement at six concentration prints $(6$ replicates at each point) working dilution of modafinil in the range of $20-120 \mu \mathrm{g} / \mathrm{ml}$ were prepared by taking suitable aliquots of working standard solution in different $10 \mathrm{ml}$ volumetric flasks and diluting up to the mark with the mobile phase. Twenty micro lot quantity of the dilution was injected each time into the column at a flow rate of $1.0 \mathrm{ml} / \mathrm{min}$. Each dilution was injected 6 times in to the column. The drug in the elutes was monitored at $220 \mathrm{~nm}$ and the corresponding chromatograms were obtained. From these chromatograms the mean peak areas were calculated and a plot of concentration over the peak area was constructed. The regression of the plot was completed by least squares regression method. A linear relationship in the range was found to the $20-120 \mu \mathrm{g} / \mathrm{ml}$ of the drug between the concentration of modafinil and respective peak area. This regression equation was later used to estimate the amount of modafinil in pharmaceutical dosage form. A representative chromatogram for the separation of modafinil is given in figure 1.

\section{Preparation of sample solution}

Twenty tablets of modafinil were weighed and powdered uniformly in a mortar. An accurately weighed portion from this powder equivalent to $100 \mathrm{mg}$ of modafinil was transferred into $100 \mathrm{ml}$ volumetric flask. The contents of the flask were sonicated for about $15 \mathrm{~min}$ for complete solubility of the drug and the volume was made up to $100 \mathrm{ml}$ with mobile phase. Then the mixture was filtered through a $0.45 \mu$ membrane filter. From the above solution $1 \mathrm{ml}$ aliquot was taken into a separate $10 \mathrm{ml}$ volumetric flask and diluted up to the volume with 
Table 1: Calibration data of the proposed method.

\begin{tabular}{ccc}
\hline $\begin{array}{c}\text { Concentration of } \\
\text { Modafinil }(\mu \mathrm{g} / \mathrm{ml})\end{array}$ & $\begin{array}{c}\text { Mean peak } \\
\text { area }(\mathbf{n}=6)\end{array}$ & $\begin{array}{c}\text { Concentration range } \\
(\mu \mathrm{g} / \mathrm{ml})=20-120\end{array}$ \\
\cline { 1 - 2 } 20 & 1548.88 & \\
40 & 3122.309 & Correlation coefficient \\
60 & 4346.061 & $\left(\mathrm{r}^{2}\right)=0.9991$ \\
80 & 5727.505 & Slope $(\mathrm{m})=66.153$ \\
100 & 7031.031 & Intercept $(\mathrm{b})=363.386$ \\
120 & 8188.787 & \\
\hline
\end{tabular}

the mobile phase and mixed well. The above solution $(20 \mu \mathrm{L})$ was then injected six times into the column. The mean peak area of the drug content in the formulation was calculated by the regression equation of the calibration plot.

\section{RESULTS AND DISCUSSION}

The present study was aimed at developing a sensitive, precise and accurate HPLC method for the analysis of modafinil in bulk drug and in pharmaceutical dosage form and forced degradation. In order to achieve optimum separation of the component peaks, mixtures of acetonitrile with phosphate buffer in different combinations were tested as mobile phase on a $\mathrm{C}_{18}$ stationary phase. A binary mixture of buffer:acetonitrile in a proportion of $55: 45 \mathrm{v} / \mathrm{v}$ was selected as the chromatographic peaks were well defined and resolved with no tailing. The retention time obtained for modafinil was $4.80 \pm 0.06$ min. Each of the samples was injected six times and the sample retention times were observed in all cases. The peak areas of modafinil were reproducible as indicated by low coefficient of variation. A good linear relationship $\left(r^{2}=0.9991\right)$ was observed between the concentration of modafinil and the respective peak areas. The regression curve was constructed by linear regression fitting and its ma-

Table 3: Robustness Study.

\begin{tabular}{|c|c|c|c|}
\hline \multirow[b]{2}{*}{ Variations } & \multicolumn{3}{|c|}{ Chromatographic parameters } \\
\hline & $\begin{array}{l}\text { Tailing } \\
\text { Factor }\end{array}$ & $\begin{array}{c}\text { Theoretical } \\
\text { Plates }\end{array}$ & $\begin{array}{c}\text { Retention } \\
\text { Time }\end{array}$ \\
\hline $\begin{array}{c}\text { Flow rate at } \\
0.9 \mathrm{ml} / \mathrm{min}\end{array}$ & 1.035 & 3411 & 5.388 \\
\hline $\begin{array}{c}\mathrm{pH} \text { of Mobile } \\
\text { phase at } 4.5\end{array}$ & 1.035 & 3411 & 5.630 \\
\hline $\begin{array}{l}\text { Wave length at - } \\
\text { 220nm }\end{array}$ & 1.055 & 3645 & 4.873 \\
\hline
\end{tabular}

Table 2: Accuracy data (Triplicate values at $\mathbf{8 0 , 1 0 0 , 1 2 0}$ percent levels).

\begin{tabular}{cccc}
\hline $\begin{array}{c}\text { *Amount } \\
\text { taken }(\mu \mathrm{g})\end{array}$ & $\begin{array}{c}\text { *Amount } \\
\text { found }(\boldsymbol{\mu g})\end{array}$ & $\begin{array}{c}\text { *Percent } \\
\text { recovery }\end{array}$ & $\begin{array}{c}{ }^{*} \text { Mean percentage } \\
\text { recovery }\end{array}$ \\
\hline 90 & 90.033 & 100.03 & 100.03 \\
110 & 109.48 & 99.527 & 99.527 \\
130 & 129.085 & 99.296 & 99.296 \\
\hline
\end{tabular}

*Each value is a mean of three readings

thematical expression was $Y=66.153 \mathrm{X}+363.386$ (Where $\mathrm{Y}$ gives peak area and $\mathrm{X}$ is the concentration of the drug). The regression characteristics are given in table 1 . When modafinil solutions were analyzed by the proposed method for finding out intra and inter-day variation, low co-efficient of variation was observed. The absence of additional peaks indicated non-interference of common excipients used in the tablets.

High recovery values obtained from the different dosage form by the proposed method indicates the method is accurate. The drug content in tablets was quantified using the proposed analytical method are given in table 2.

The deliberate changes in the method have not much affected the peak tailing, theoretical plates and the percent assay. This indicated the robustness of the method. The robustness study results are presented in table 3 . The lowest value of LOD and LOQ as obtained by the proposed method indicates the sensitivity of the method. The standard solution of the drug was stable up to $24 \mathrm{hrs}$ as the difference in percent assay during the above period is within limit. System suitability parameters were studied with six replicates standard solution of the drug and the calculated parameters are within the acceptance criteria. The tailing factor, the number theoretical plates are in the acceptable limits. The system suitability results are shown in table 4 .

The system precision was established by six repli-

Table 4: System Suitability Parameters.

\begin{tabular}{cc}
\hline Parameters & Value \\
\hline Theoretical Plates $(\mathrm{h})$ & 3420 \\
Tailing factor $(\mathrm{T})$ & 1.017 \\
LOD $(\mu \mathrm{g} / \mathrm{ml})$ & 2.356 \\
LOQ $(\mu \mathrm{g} / \mathrm{ml})$ & 7.140 \\
\hline
\end{tabular}


Table 5: Forced Degradation.

\begin{tabular}{lcccccc}
\hline Drug Name & Condition & Time & $\begin{array}{c}\text { RT } \\
(\mathbf{m i n})\end{array}$ & Area & \% Degradation \% of Active drug Present after Degra- \\
& & & & & dation \\
\hline \multirow{4}{*}{ Modafinil } & Control Sample & 00 & 4.986 & 7983.69 & $0.2 \%$ & $99.8 \%$ \\
& Acid Degradation & 24 & 4.980 & 7897.38 & $7.85 \%$ & $92.15 \%$ \\
& Alkaline Degradation & 24 & 4.980 & 6835.49 & $7.38 \%$ & $92.62 \%$ \\
& Thermal Degradation & 24 & 4.960 & 7181.54 & $4.55 \%$ & $95.45 \%$ \\
\hline
\end{tabular}

cate injections of the standard solution containing analytes of interest. The value of relative standard deviation (0.666) was found to be within the limit, indicating the injection repeatability of the method. The method precision was established by carrying out the analysis six times using the proposed method. The relative standard deviation (0.662) was found to be within the limit, indicating the injection repeatability of the method.

The specificity of the HPLC method was determined by the complete separation of modafinil. When it was subjected to forced degradation as per ICH guidelines which was carried out with $0.1 \mathrm{~N} \mathrm{HCL}$, $0.1 \mathrm{~N} \mathrm{NaOH}$ and Heat degradation at $105^{\circ} \mathrm{C}$. The method does not permit detection of degradation product for modafinil. The results of specificity data for degradation study are given in table 5 .

Hence it can be concluded that the proposed HPLC method is sensitive and reproducible for the analysis of modafinil in pharmaceutical dosage form with short analysis time of $8 \mathrm{~min}$.

\section{ACKNOWLEDGEMENT}

The authors are thankful to $\mathrm{M} / \mathrm{s}$ Orchid Laboratories, Chennai, India for providing gift sample of modafinil and formulations. The authors are also thankful to the Department of pharmaceutical analysis, Prist university, Thanjayur, Tamilnadu; Principal, Dr. K.V. Ramana and Correspondent, A. Siva Kumar, A.S.N Pharmacy College, Guntur(Dt), Andhra Pradesh for encouragement and providing laboratory facilities.

\section{REFERENCES}

Burnat, P., Robles, F., Do, B. (1998). High-performance liquid chromatographic determination of modafinil and its two metabolites in human plasma using solid-phase extraction. J Chromatogr BBiomed Sci Appl, 706(2):295-304. DOI
Cass, Q.B., Galatti, T.F. (2007). A method for determination of the plasma levels of modafinil enantiomers, $( \pm)$-modafinic acid and modafinil sulphone by direct human plasma injection and bidimensional a chiral-chiral chromatography. Journal of Pharmaceutical and Biomedical Analysis. 46(5): 937-944. DOI PMid:17478071

Donovan, J.L., Malcom R.J., Markowitz, J.S., DeVane, C.L. (2003). Chiral analysis of d- and l-modafinil in human serum: application to human pharmacokinetic studies.

Therapeutic Drug Monitoring. 25(2): 197-202. DOI PMid:12657914

Moachon, G., Matinier, D. (1994). Simultaneous determination of modafinil and its acid metabolite by highperformance liquid chromatography in human plasma. J Chromatogr B Biomed Appl. 654 (1): 91-96. DOI

Nageswara R.R., Shinde, D.D., Kumar Talluri, M.V. (2007). Development and validation of a reversed phase liquid chromatographic method for separation and determination of related-substances of modafinil in bulk drugs. Talanta.73(3): 407-414. DOI PMid:19073048

Schwertner, H.A., Kong, S.B. (2005). Determination of modafinil in plasma and urine by reversed phase highperformance liquid-chromatography. Journal of Pharmaceutical and Biomedical Analysis. 37(3):475-479. DOI PMid:15740906

The Merk index, $13^{\text {th }}$ Edition, Merk \& Co., INC., Whitehouse station, NJ; 2001, 6249.

Yu, E., Chovan, J.P. (1999). A HPLC method for the determination of modafinil and modafinil acid optical isomers in biological matrices. The AAPS Journal. Volume 1. 